\title{
Debt-Based Versus Equity-Based Financing: A Comparative Analysis on Efficiency of Islamic Financial System
}

\author{
Abdullateef Abdulqadir Maikabara ${ }^{1 *}$, Sri Maulida², \\ Abdulmajeed M.R Aderemi ${ }^{3}$ \\ ${ }^{1}$ IIUM Institute of Islamic Banking and Finance (IIiBF), International Islamic \\ University, Kuala Lumpur, Malaysia \\ ${ }^{2}$ Faculty of Economic and Business, Universitas Lambung Mangkurat, \\ Kalimantan Selatan, Indonesia \\ ${ }^{3}$ Faculty of Business and Management, Universiti Sultan Zainal Abidin, \\ Terengganu, Malaysia \\ *abdulqadirm2018@gmail.com
}

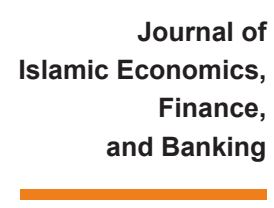

Vol. 4, No. 1, June 2021, pp. 1-13, ISSN p:2622-4755 e:2622-4798

\section{Article History}

\begin{tabular}{lll}
\hline Received & $:$ & $2020-12-02$ \\
\hline Revised & $:$ & $2020-12-19$ \\
\hline Accepted & $:$ & $2020-12-21$ \\
\hline
\end{tabular}

\section{Abstract}

Introduction to The Problem: The financial system, as a subset of economics, plays a prominent role in solidifying the socio-economic development and wellbeing of people of a society. However, debt-based and equity-based financing are the main models employed by Islamic financial institutions to help small and medium enterprises (SMEs) that need funding to facilitate their businesses' projects. Operationally, debt-based financing seems to be the prominent financing model rather than equity-based financing, which only accounts for either zero or small scale in Islamic financial institutions.

Objective Study: This study explores the rightful financing model that can contribute much better to the efficiency of the Islamic financial system in achieving socio-economic development.

Methodology: To achieve the study's purpose, a literature-based method and secondary data collection technique are adopted as related previous studies from articles, books, conferences, and working papers are reviewed and analyzed.

Findings: Equity-based model as a partnership model is somewhat more productive in contributing to socio-economic development than debt-based financing, but not being widely applied due to specific issues such as high risk, agency problem, costumer's awareness, and sensitivity, and others more. It is recommended that researchers empirically investigate the suitable financing

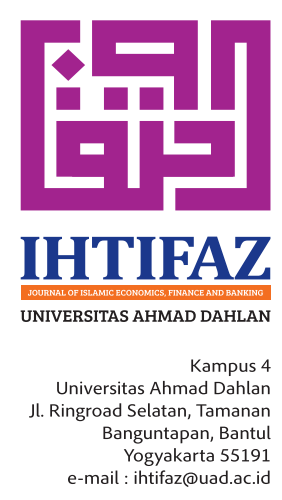


model between debt-based and equity-based financing models to ensure the achievement of sustainable socio-economic development.

Keywords: Debt; Equity; Financing; Islamic; Islamic financial System

\section{INTRODUCTION}

The financial system is a subset of economics, which plays a prominent role in building society's well-being with different paradigms and schemes for strengthening economic growth positively, which will eventually affect the livelihood of the citizens. However, debt and equity models were being employed by the financial institutions, public and private organizations to help large, small, and medium enterprises in carrying out their financial plans and initiatives. Surprisingly, the former seems to be the priority of financial institutions more than the latter in both conventional and Islamic financial systems due to some issues, i.e., self-interest and inclination, mostly in the conventional system. Also, the debt-based was considered as the root problem behind the financial crisis that occurred in 2008 whereby people are with a huge amount of debt on their neck because of the debt financing issued that is based on a loan with interest that was compounded later on due to incapability of repaying the loans borrowed. Islamic financial system was foreseen to be an alternative to the conventional system in saving any financial crises. Still, inadvertently, Islamic banking in practice seems to be closely the same as its conventional counterpart, which is heavily based on debt financing. However, Sharia principles using underlying Islamic contracts distinguish it from the conventional paradigm. Notably, the debt-based banks take the high percentage in Islamic banks. Equitybased takes the remaining low percentage due to some issues such as the issue of moral hazard associated with the ex-post information asymmetry, which is more likely to occur with equity financing contracts; Musharakah and Mudarabah (Abdurrahman, 2015; Ariffina et al., 2015; Fianto et al., 2018).

Lack of awareness of equity-based financing model features and operational paradigm as many Islamic bank consumers have zero or little knowledge about the financing model, which is relatively new in the banking system compared to the prominent debt-based financing model (Fianto et al., 2018; Madun et al., 2015). Intensively, it is quite important for the Islamic financial system as an alternative to the conventional system for solving social problems and providing its needs and wants to choose and explore the right mode of financing its client's plans to tackle financial crises and lead the world to a bright one, not the worse one. In this paper, the nature of debt-based financing and equity-based financing will be explored in a comparative study discussing the right alternative model of financing that contributes much better to the Islamic financial system's efficiency. 
In an attempt to achieve the research objective, this study is organized into several sections. Following the introduction, Section two captures the results and discussion about the concept of debt-based financing and equity-based financing in both Islamic and conventional viewpoints; Islamic financial system and financing modes, as well as the efficiency of the Islamic financial system and the last section, presents the concluding remark and recommendations.

\section{RESULTS AND DISCUSSION}

Based on the available secondary data gathered from previous studies that addressed Islamic financing's conceptual and operational dimensions, this section reviewed and analyzed the studies as it dwells on the concept of debt-based and equity-based financing, Islamic financial system, and financing modes. More importantly, it highlighted the efficiency of the Islamic financial system by promoting the equitybased financing model.

\section{Concept of Debt and Equity-Based Financing}

Basically, in any financial system, the funds are raised based on two financing models either by exploring equity-based or debt-based. However, these two modes of financing are being used in both conventional financial Systems and the Islamic financial system as a financial alternative for executing any financial plans by a business organization such as small and medium enterprises and individual activities. In operation, each financial system has a different structure with different paradigms due to each system's principles that conceptualize its framework.

On the one hand, in the conventional financial system, projects are financed either through equity or debt-based financing. In general, the integer part of the activities taken out in the conventional mode of financing is the interest charge on any project, most especially in debt-based whereby the lender raise funds for to the borrower with an agreement of paying back the capital with an additional interest to be received over some time in exchange for risking his/her money for funding the project. Conversely, in Equity financing groups of people come together to form an operational partnership business. Each of them contributes with a sum of capital; this thus results in the degree of owning shares or shares depending on the contribution. In some cases, an individual may serve as a sole proprietorship, and the financing would be in the form of an owner's contribution.

On the other hand, in the Islamic financial system, the modes of financing are the same as that of the conventional system based on debt and equity. Still, the Shariah principles distinguish it from the conventional form. In the Islamic financial system, the two main modes of financing (Equity and Debt) are the norms of their activities in conjunction with Islamic commercial contracts. Practically, debt-based financing is a mode 
of financing based on underlying contracts that are frequently used in Islamic for financing, e.g., home financing, vehicle financing, and others. IHTIFAZ - JIEFB The instrument for this model of financing arises from sale transactions. These include Bay'murabaha (makeup sale), bay al-salam (advance sale), Bay'istisna (manufacturing contract), Bay'al-muajal (credit sale), Bay'bithaman ajil (deferred payment contract), Ijarah (leasing contract) (Hassan, 2011; Ryandono \& Wahyudi, 2018) and partially Musharakah Muthanaqisoh (diminishing Musharakah). More so, equity-based financing is a mode of financing under the partnership contracts based on profit and loss sharing between two parties. The underlying contracts are the Musharakah (profit and loss-sharing) and Mudarabah (profit sharing), and partially Musharakah Muthanaqisoh (diminishing Musharakah). All these equity partnership modes are considered to be commonly practiced in the banking system. The equity-based financing constitute investment activities which involves real economic activities by two or more parties entering into a contract and contributes to the capital or management of partnership with similar rights and liabilities by taking the risk and at the same time with an attainable amount of profit and loss to be shared by them according to the proportional ratio as in Musharakah and profitsharing in Mudarabah (Hassan, 2011; Sapuan, 2016).

\section{Islamic Financial System and Financing Models}

Financing is one of the financial institutions' roles in both conventional and Islamic financial systems to facilitate the economic units' business cycle and contribute to economic growth. However, the banking system employs two financing models, which are debt and equity-based on financing micro, small, and medium enterprises (MSMs). The Islamic financial system is considered an alternative to the conventional system, mostly based on interest / debt-based financing. Surprisingly, it seems to be operating as its counterpart. The debt-based Islamic financial products like Murabahah seem to dominate the larger scale in the Islamic financial institutions than equity-based financing.

Interestingly, the discussion about the suitable and sustainable financing model in the Islamic finance industry has boosted researchers' attention, most especially after the financial crisis that occurred in 2008 due to the huge mountains of debt as one of the main factors. This posted an evaluation of the structures of the two models using conceptual and empirical studies to develop a significant outcome in relation to the public interest and socio-economic development. Rigorous studies have been conducted on the operational ecosystem of the debt-based and equitybased financing model in which some of them stressed the pressing issues behind the dominance of the debt-based model in Islamic financial institutions and some, on the other hand, captured the importance of the equity-based model being more Sharia-compliant embedded with a risk-sharing domain. 
A study conducted by Yusof et al. (2009) explored a case study on Islamic Finance in the context of debt-based and equity-based financing, judging both models of financing in the light of Maqasid al-Sharia( objectives of Sharia) but mostly focused on debt-based. In his article, he attempted to answer a question, which is: "...Are these debt-based contracts a viable alternative about fulfilling the Maqasid Sharia and economic justice, or are they just mirror images of conventional debt financing products having negative implications on society? He concluded that debt based is not comforting to the principle of justice and not in the debate to a sensitive to the needs of the society as its vision believed by Doctor Wahbah Al-Zuhayli in his book entitled " Al-Fiqh Al-Islamy wa-Adillahtuh," the author believes that that could be achieved if Islamic banking can solve macro-economic shocks on equity financing rather than debt financing.

Khan (2015) used a comparative study highlighting some implications of debt-based and equity-based financing in the situation of finance crisis occurrence. The study attempted to measure the two financing models, exploring some testable hypotheses, theoretical and philosophical discussions. It addressed the impact of money generation, stability of price, and return. Critically, the article highlighted the impact of debt-based financing and risk transformation on aggregate risk in an economy. It focuses mostly on replacing debt-based financing with equity-based financing and prescription of wakalah-ju'alah as a financing alternative. Also, it provides some reasons behind the absence of true risk-sharing contracts (Musharakah and Mudarabah) as practiced in the Islamic finance industry. However, Lewis (2015) proclaimed that Islamic banks use debt and equity contracts. Still, in operation, it is somehow a way of emulating conventional structure due to a sensitive situation in competing with their conventional counterpart. Surprisingly, the equity-based financing model's practice is either absent or low in the Islamic finance industry; for instance, in Malaysia, no microfinance institution offer equity-based contacts, Musharakah and Mudarabah (Islam \& Ahmad, 2020). Meanwhile, according to Ariffina et al. (2015), Musharakah Muthanaqisoh is been applied as an equity financing mode by a very few Islamic banks in Malaysia as the banks are reluctant of practicing the equity financing modes due to complexity of their nature compared to conventional financing modes even though the respondents of the study believe that the equity-based financing constitutes the real ecosystem of Islamic banking.

Madun et al. (2015) explored the challenges on the marketing of equity-based financing product Islamic Banking; the main purpose of the research is particularly to investigate the new equity-based financing and Islamic banking products generally, and a subset of it is to report and provide insights on the challenges encountered particularly by new financial product and Islamic banking in general. This was done by 
visual communication with banking officials and an interview conducted with customers of different Islamic banks. Similarly, Maikabara (2019) IHTIFAZ - JIEFB addressed the issues and challenges behind the reliance of Islamic banks on debt-based financing more than equity-based financing as he noted some major issues that trigger the great promotion of equity-based financing, namely, high risk, capital guarantee, information asymmetric, cost of special business skills, and lack of consumers' awareness about equity financing.

Meanwhile, even though many Islamic financial institutions have not widely practiced the equity-based model, some studies have shown that the model plays a prominent role in contributing to socio-economic. It has established a positively significant performance compared to the debt-based financing model. Abdul-Rahman et al. (2014) assessed the improvement of Islamic banking institutions' operational ecosystem in Malaysia based on the New Institutional Economics (NIE) theory to unlock the Islamic bank's potential towards entrepreneurship rather than serving as financial intermediaries. The author argued that the profitloss sharing (PLS) contracts, which are the instruments of facilitating entrepreneurship, would be operationally practiced if the Islamic banks genuinely play entrepreneurs' roles.

Fianto et al. (2018) highlighted the impact of Islamic microfinance on Indonesia's rural household welfare using a survey questionnaire conducted on Islamic microfinance institutions in Indonesia. The study explored the two financing models in Islamic microfinance, equitybased and debt-based financing, by examining their impact on rural households. About this, it evaluated Sharia compliance based on the National Sharia Board of Indonesia. Nevertheless, the result shows a positive and significant impact of both debt and equity-based on rural households' income. Still, equity-based financing takes a higher performance than debt-based financing.

Islam \& Ahmad, (2020) examined the viability of the two equitybased modes, Mudarabah and Musharakah contacts, for financing underprivileged women entrepreneurs in the Selangor state of Malaysia. The study examined the clients' awareness to accept Sharia principles, religiosity, product knowledge, and entrepreneurial skills. The findings revealed that even though the clients have primary knowledge about the contacts, their preference is mainly on a simple, comprehensive product that can meet their interests and preserve fair religious practice. However, on the other hand, there is a lack of entrepreneurial skills among the clients, which has to be addressed with constructive measures to ensure effective promotion of the equity-based modes.

Rahman et al. (2020) addressed the adoption of Musharakah contract to finance potential business entrepreneurs. However, in mitigating possible risks, the authors suggested adopting five Venture capital strategies, namely, method of selection, fund channeling, 
monitoring, non-capital assistance, and investment periods. Also, in applying the strategies, corporate social responsibility funds can be channeled for Musharakah financing. It is credible to note that these suggestions could be deployed as part of the necessary measures in realizing the sustainable potential of equity financing in Islamic financial institutions.

Remarkably, It is worth-mentioning to note that some studies

Journal of Islamic Economics, Finance, and Banking

Vol. 4, No. 1, June 2021, Pp. 1-13, ISSN p:2622-4755 e:2622-4798 assessed the relationship between debt-based and equity-based financing and profitability of Islamic banking (Duncan, 2013; Mariam, Isnurhadi \& Taufik 2017; Wahyudi et al., 2020; Wahyudi, Mujibatun \& Riduwan 2019) Some of the findings reveal that the debt-based financing contributes to Islamic banking's profitability than the equitybased financing (Duncan, 2013; Mariam et al., 2017) On the other hand, the findings of Wahyudi et al. (2019) show that both the debt-based financing and equity financing affects the performance of Islamic banks as well as the bank size does not moderate the relationship between the financing models and profitability in the study area. Meanwhile, Wahyudi et al.(2020) found that debt-based financing has more influence on ROE of Islamic banks than equity-based financing. Relatively, both the debt-based and equity-based financing do not fully affect ROA of Islamic banks as well as the selected independent variables of both the two financing models have a strong effect on the profitability variables; ROA AND ROE.

From the afore-captured literature, it can be noted that even though many studies have addressed the pivotal role of equity-based financing as an alternative to debt-based financing, the debate is still inconclusive precisely to the ecosystem of the Islamic financial system, which is supposed to heavily promote the risk-sharing financing as one of the major attributes that distinct Islamic finance from its conventional counterpart. Some articles post a question on whether to raise debt or equity for financing business ventures. Some broadly assess which financing model is more in line with Maqasid Shariah (Objectives of Shariah). Khan (2015) conducted a comparative study on the implication of debt-based and equity-based financing in the Backdrop of Financial crises as entitled by him. He posted huge evidence on the issue of replacing debt-based financing with equity-based financing. According to him, equity-based financing is referred to as an alternative model based on Islamic finance principles in a situation where the underlying contracts operate within the norm of risk-sharing. In light of this, the following section attempts to articulate some of the major dimensions in which the equity financing model can potentially constitute a significant contribution to the efficiency of the Islamic financial system in facilitating socio-economic development and sustainability compared to the dominant debt-based financing model in the Islamic financial institutions. 


\section{The Efficiency of the Islamic Financial System}

IHTIFAZ - JIEFB

Surprisingly, there is no such distinction between the practice of the Islamic financial system and its conventional counterpart in terms of provision of financing businesses and individuals as both engage in financing using debt-based more predominantly than the equity-based. In contrast, the latter tremendously contributes to socio-economic development but is practiced in a small range due to several issues such as the risk involved, market demand, and others as addressed above. However, this section elucidates equity-based financing's great potential to productively contribute to socio-economic development and sustainability. However, it is crucial to note that one of the main factors that distinct Islamic finance ecosystem from the prominent conventional operation is the religious, ethical element that constitutes fairness and justice and promotes mutual assistance amongst individuals for ethical socially responsible business engagement and equitable socio-economic wellbeing. The potential role of equity-based financing as a productive tool in achieving socio-economic development is critically discussed as follows:

\section{Problem-Solving}

One of the Islamic financial system aims is to solve the financial problem by raising funds to finance short term and long-term plans. Ultimately, the right way to safeguard financial stability and wellbeing circulation within an economic ground is for financial institutions to promote equity-based financing and abstain from undertaking debtbased financing using Murabahah, salam, and others. This does not mean those contracts that are based on future delivery or deferred payments are not good; they are actually engaging in convenience delivery and payment but not really that effective because mostly the risk and loss will be transferred to another party only and has to unfairly bear the consequence-in contrast, engaging in equity financing that is based on Musharakah and Mudarabah contracts which are for investment and venture partnership domains with profit and loss sharing paradigm. This could solve any dispute that might occur in fulfillment of binding agreement due to incapability as both parties have to share the profit and loss incurred.

\section{High Investment Return}

Investors intuitively strive for a higher return from the investors' perspective than gaining one or two pounds out of what they invest in. If a huge amount of money from one thing is guaranteed, more will be invested. Comparatively, in debt-based financing, the marginal profit from financing a project, vehicle, home, etc., is lower than it would be in a joint partnership. In the former, the only financier will gain additional profit together with the capital from financing. Simultaneously, in the latter, both the two parties share profit from the investment according to their capital contribution. Usually, the higher rate of investment return

Ihtifaz: Journal of Islamic Economics, Finance, and Banking 
from equity is huge, unlike in debt financing. Equity financing as an entrepreneurial financing model has the great potential to significantly serve the investor's and entrepreneurs' financial preferences across the globe (Biancone \& Radwan, 2017) if necessary criteria and effective management strategies are incorporated.

\section{Financial Stability}

The causative of financial crisis emerged partly from monetary theory model linking with the engagement of banks in debt-based financing while creating money out of lending with interest as in the conventional system of banking or generation of money from debt-based out after entering into financing using equity financing as enumerated earlier in the case of diminishing Musharakah offered by Islamic banks. Hence, the Islamic financial system is a non-interest-based financing system. Still, it also involves debt as the market demands debt-based financing rather than equity-based financing for reasons like its simplicity, even though it is more productive than realizing financial stability as the people engage in investment and not only depend on lending, which could increase falling in the danger zone. Thus, the investment rate would yield high returns and a stable financial stand as they involve themselves in investment activities.

\section{Employment Opportunity and Durability}

Engagement in debt-based financing offered by financial institutions could cause someone to lose his job while paying off his short- or long-term debt. This is the consequence and tackles employment opportunities for individuals and businesses because the debt is a cost. As the cost gets higher, companies will try to allocate resources by getting some employees fired, in most cases to minimize the cost, and no door will be opened for the potential and skillful person to be hired. Contrarily, the equity-based financing promotes employment durability and provide job opportunity as the expected return getting higher and higher, the financier and investors will be motivated to employ more workers in other to maximize profit ethically and rightfully as prescribed in Islamic commercial law relating Islamic transaction, comfort the Maqasid Shariah (objectives of Sharia) and serve the principle of Maslaha (public interest). The most important element in any business activity is to realize the Sharia requirements and conditions embedded with the contract (Yusof et al., 2009).

\section{Wealth Circulation}

In a comparative approach, equity-based financing plays a crucial role in the circulation of wealth within the economy as a whole, unlike debt-based which only bound to transfer an asset to another party mostly with debt to be paid in a future time, and only the financier will benefit most with a specific return or profit. However, engaging in equity-based 
financing comes with a higher profit than that of debt. At the same time, both parties (i.e., bank and its client) both the two parties join IHTIFAZ - JIEFB

hands together as partners and invest their capital, management, and efforts on a project financing instead of carving out a debt-based model. Although it contains high risk due to the possibility of gaining or losing if the outcome turns out successfully, the profit will be guaranteed, and the loss will be shared. As a result of the return shared between the two parties, the wealth circulation between the rich and poor could surely be established. Hence, that would positively contribute to the standard of living and strengthen the community's economic growth.

\section{Impact on GDP}

All the problems caused by debt-based financing will affect the GDP and subsequently, harm the wellbeing of society due to the mountainous debts and blockage of a financial return in one direction, not in a circulative parameter within the country as a whole, only the financier will benefit from it, and the debtor will only be having a debt nightmare. Contrastingly, engaging in equity investment boosts the GDP, and eventually, economic growth and development would be promoted.

\section{Social Impact}

Access to finance is considered one of the factors that constitute socio-economic welfare in any society, especially for the rural poor and unprivileged small businesses. The social impacts include better education, health, and housing for the poor. This cannot be ascertained well with inclination on the debt-based financing contract. Still, all these aims can be achieved in equity-based financing through a well-organized and regulated financing operation (Hermes \& Lensink 2011). Equitybased financing would be more productive in contributing to the people's livelihood, especially the unprivileged individuals, by empowering them through the partnership financing contracts such as Musharakah and Mudarabah. In the first contract, the financial institution will execute a contractual agreement with individuals and enterprises that potentially have a healthy financial status and are creditworthy to ascertain financial obligations. While in the latter, the partnership will be executed with financially unprivileged individuals but have management potential and skills to manage a business by financing them and then sharing the profits based on the pre-agreed ratio. Thus, the partnership would yield great financial benefits for both parties, especially the manager, and navigate a remarkable sustainable socio-economic development than employing the debt-based financing model, which creates a bunch of debts rather than creating financial independence and entrepreneurial productivity. This social element is an integral attribute of Islamic finance being an ethical financial system that promotes not only religious responsibility but rather social welfare through socially responsible investments (Biancone \& Radwan 2016). 


\section{CONCLUSION}

Islamic financial system plays a crucial role in promoting financial activities, channeling funds between the two economic units, surplus unit and deficit unit. Two models of financing are being employed by a financial institution, governmental and non-governmental. Namely: Debt-based financing and equity-based financing. However, in order for the system to be engaging in its financial activities, it is imperative to explore a comparative empirical study to investigate the effective mode that could pose a paramount contribution to the efficiency of the Islamic financial system. The research shows that equity-based financing can contribute to the efficiency and sustainability of the Islamic financial system to ensure socio-economic development. Also, equity-based financing is more suitable for the Islamic financial system's efficiency to achieve Sharia's objectives. In this regard, it is crucially important for policymakers to proactively employ necessary and collective measures to facilitate equity-based financing to ensure the effective role of the Islamic financial system to achieve socio-economic development and sustainability. It is highly recommended to integrate financial technologies (i.e., Blockchain, IoT, AI, Smart contract) with the equity financing model as part of the measures to tackle the issues challenging the promotion of the model and unlocking its potential for achieving sustainable socio-economic development. Finally, further research is suggested to conduct an empirical investigation assessing the efficiency of the Islamic financial system using the equity-based financing model and its sustainability as an alternative tool of financing. Also, empirical studies should be conducted on the effects of the model on non-financial performance of Islamic financial institutions.

\section{REFERENCES}

Abdul-Rahman, A., Abdul Latif, R, Muda, R. \& Abdullah, M. A. (2014). Failure and potential of profit-loss sharing contracts; A perspective of New Institutional, Economic (NIE) Theory. Pacific Basin Finance Journal, 28, 136-151.

Abdurrahman, S. (2015). Bringing Islamic Banks Closer to the ideal: From Debt-Based Financing to Equity-Based Modes. Proceeding - Kuala Lumpur International Business, Economics and Law Conference,7 (KLIBEL 2015).

Ariffina, N.M., Kassim, S., Abdul Razak, D. (2015). Exploring application of equity-based financing through mushārakah mutanāqisah in Islamic banks in Malaysia: Perspective from the Industry Players. International Journal of Economics, Management and Accounting, 23 (2), 241-261.

Biancone, P.P. \& Radwan, M. (2016). European Comapanies: Evaluation For Sharia Compliance "Opportunities And Challenges." European Journal of Islamic Finance, 5.
Journal of

Islamic Economics,

Finance,

and Banking

Vol. 4, No. 1, June 2021, pp. 1-13, ISSN p:2622-4755 e:2622-4798 
Biancone, P.P \& Radwan, M. (2017). International Entrepreneurship from an Islamic (Sharia Compliant) Perspective "The Opportunities for Western Economies". World Journal of Accounting, Finance, and Engineering, 1 (1).

Duncan, M. (2013). The effect of debt financing on firm profitability of commercial banks in Kenya. In Master of Business Administration. University of Nairobi.

Eddy Yusof, E. F., Kashoogie, J., \& Anwar Kamal, A. (2009). Islamic Finance: Debt versus Equity Financing in the Light of Maqasid alShari'ah. Munich Personal RePEc Archive (MPRA), Paper No, 20722.

Fianto, B. A., Gan, C., Hu, B., \&, \& Roudaki, J. (2018). Equity financing and debt-based financing: Evidence from Islamic microfinance institutions in Indonesia. Pacific-Basin Finance Journal, 52, 163-172.

Hassan, R. (2011). Islamic Banking and Finance (2nd Editi). Petaling Jaya, Selangor Darul Elsan, Malaysia: Pearson Malaysia Sdn Bhd.

Hermes, N., \& Lensink, R. (2011). Microfinance: its impact, outreach, and sustainability. World Development, 39 (6), 875-881.

Islam, R. \& Ahmad, R. (2020). Applicability of Mudarabah and Musharakah as Islamic Micro-equity Finance to Underprivileged Women in Malaysia. European Journal of Development Researc, 32 (1), 176-197.

Khan, H. (2015). Some implications of debt versus equity-based financing in the backdrop of financial crises. Journal of King Abdulaziz University: Islamic Economics, 28 (1), 165-180.

Lewis, M. (2015). Models of Islamic banking: The role of debt and equity contracts. Journal of King Abdulaziz University: Islamic Economics, $28(1), 151-164$.

Madun, A., Kamarulzaman, Y., \& Roslan., \& N. F. Z. (2015). The Challenges on the marketing of Equity-based financing products of Islamic Banking. International Conference on Islamic Marketing and Branding Proceeding, 161-180.

Maikabara, A. A. (2019). Why Islamic Banks Focus More on Debt-Based Financing Than Equity-Based Which Is More Shariah Compliant?. Available at SSRN Electronic Journal.

Mariam, N.S., Isnurhadi, \& T. (2017). The Impact of Debt Financing and Equity Financing on Profit Expense Ratio of Islamic Banks in Indonesia. JEMBATAN-Jurnal Ilmiah Manajemen Bisnis Dan Terapan, 14 (2).

Rahman, A. A., Nor, S. M., \& Salmat, M. F. . (2020). The application of venture capital strategies to musharakah financing. Journal of Islamic Accounting and Business Research, 11 (3), 827-844.

Ryandono, M. N. H., \& Wahyudi, R. (2018). Manajemen Bank Islam: Pendekatan Syariah dan Praktek. UAD Press. 
Sapuan, N. M. (2016). An evolution of Mudarabah contract: a viewpoint from classical and contemporary Islamic scholars. Procedia Economics and Finance, 35 (3), 349-358.

Journal of Islamic Economics, Finance,

Wahyudi, R., Diniyya, A.A., Satyarini, J.N.E, Mutmainah, L. \& Maulida, S. (2020). The Effect of Debt-Based Financing and Equity-Based Financing on Islamic Banks Profitability in Indonesia. International Journal of Islamic Business and Economics, 4 (2), 106-114.

Vol. 4, No. 1, June 2021, pp. 1-13, ISSN p:2622-4755 e: $2622-4798$

Wahyudi, R., Mujibatun, S., \& Riduwan, R. (2019). Debt and Equity Based Financing: Size, and Islamic Banks Profitability: Empirical Evidence from Indonesia. IQTISHADIA, 12 (2), 227-239. 